\title{
Can SME exchange really play a vital role in accelerating Start-Up Growth?
}

\author{
ApoorvRanjan Sharma \\ VentureNursery \\ India \\ Balvinder Shukla \\ Amity University \\ Uttar Pradesh \\ India \\ S.K. Jain \\ Shri. Mata Vaishno Devi University \\ Katra, J\&K \\ India \\ Manoj Joshi \\ Amity Business School \\ Amity University, Lucknow \\ India
}

\begin{abstract}
Purpose: The purpose of this research is to understand whether SME Exchange can really play a vital role in accelerating small and medium enterprises (SME's) and Start-ups growth. Can it create an effective alternative source of funding for Incumbent SME's who are facing problems of fund raising due to weak debt market and non-availability of public market for small and medium size ventures?.
\end{abstract}

Methodology/Sampling: Structured interview were conducted with cofounders of SME's and start-ups who have raised capital from SME Exchange or likely to raise capital.

Findings: SME's are finding SME Exchange a cost effective alternative to raise capital from public market. Bank loan and private equity / Venture capital investments have their own limitation.

Practical Implications: SME Exchange can visibly impact the fund raising alternative for SME's and start-ups and therefore impact the overall growth of SME's.

Keywords: SME, Fund Raising, Start-ups, Growth, Entrepreneurship, Accelerator.

JEL Classification: L84, M13.

\footnotetext{
* The material presented by the authors does not necessarily portray the viewpoint of the editors and the management of the Institute of Business \& Technology (IBT).

* ApoorvRanjan Sharma: aprshp@yahoo.com

* Balvinder Shukla: bshukla@ amity.edu

* S.K. Jain: skjain51@ hotmail.com

* Manoj Joshi: manoj.joshi.m@gmail.com

CJMSS is published by the Institute of Business and Technology (IBT). Main Ibrahim Hydri Road, Korangi Creek, Karachi-75190, Pakistan.
} 


\section{INTRODUCTION}

SME as a sector accounts for about 95 percent of the industrial units, almost 40 percent of the gross industrial value added in the Indian economy, 34 percent of the exports and contributes to 7 percent of the Indian Gross Domestic Product (GDP). There are approximately 3.6 million registered SME's providing employments to roughly 20 million individuals (Asian Development Bank, 2012).

Every solution in the world arises out of a 'need'. The key difference is whether the solution applies to a 'need' that is created or to a 'need' that already exists. In the case of Small and Medium Enterprises (SME's) in India, there exists a 'need', the need to mitigate the financial pains of the start-up phase.

While we do not wish to get into every single 'need' of a start-up, we have narrowed our focus on the 'need for access to cost effective capital' for the SME in India. The objective of this research paper therefore is to gauge whether setting up an exchange for SME's would facilitate the growth of start-ups in India by providing a solution to an important "need", in other words known as capital requirement.

To begin with we analysed the entrepreneurs in the services and manufacturing sector in India who were classified as SME's. A common thread, observable across all the small businesses we encountered, was the requirement of funding in the early stages. A few businesses had managed to obtain funding after several unsuccessful attempts; others were struggling to stay afloat, while a few others had shut operations due to the lack of capital. Financial institutions that were created to provide capital to the entrepreneurs were either denying funding altogether or demanding astronomical interest rates that would wipe out the profitability of these small firms.

The task force report released by the Ministry of Micro, Small and Medium Enterprises (MSME) reported that the top four major issues concerning the sector are lack of availability of adequate and timely credit, high cost of credit, collateral requirement and limited access to equity capital. The situation in India, however, has been improving with the government along with Small Industries Development Bank of India (SIDBI) stepping up efforts to lend credit to the SME's under the Credit Guarantee Fund Trust for Micro and Small Enterprises (CGTMSE). Nevertheless, financing start-ups in India is yet an important concern.

This led us to pursue the scenario of SMEs financing in other countries across the globe and measure how India stacked up against them. On the Capital Access Index scale, India stood at the $47^{\text {th }}$ position among 122 nations. A review of the nations that had a higher score revealed that almost 70 percent of the economies had an alternate exchange for SME's that ensured capital was available at a fair cost according to the needs of the business. Analysing the Indian scenario in particular, our most developed financial component, Equity Markets (ranked 22 out of 122 nations), was out of bounds for the SME sector. India also ranks poorly in accessing international funds for running small and medium businesses (Angkinand et al, 2009).

We came across more than 57 countries around the globe where a version of an SME or alternate exchange exists to help small and medium companies obtain financing. The top SME exchanges of the world based on market capitalization, number of companies listed and funding raised are AIM (U.K), TSX (Canada), SPI Extra (Switzerland), Kosdaq (South 
Korea), Growth Enterprise Market (Hong Kong) and Mothers (Japan). These exchanges have been successful to a great extent in achieving their goal.

After interviewing SME business owners in India, we realized that an SME exchange was very much the need of the hour. An analysis of our shortcomings in Over The Counter Exchange of India (OTCEI) and Indonext revealed that the exchanges failed mainly because of liquidity and lack support from the financial community.

We could afford mistakes in the past, when the world was not watching. But as different India today, with global reach and fame, our next effort to set up an SME exchange will be closely watched and monitored by a lot of economies. If we are successful, the next decade of growth will clearly belong to the Small and Medium business owners of India.

\section{SMALL AND MEDIUM ENTERPRISES (SMES)}

SME as a sector accounts for about 95 percent of the industrial units (Asian development Bank, 2012), almost 40 percent of the gross industrial value added in the Indian economy, 34 percent of the exports and contributes to 7 percent of the Indian Gross Domestic Product (GDP). There are approximately 3.6 million registered SME's providing employments to roughly 20 million individuals. Small and Medium Enterprises (SME's) in India are defined (MSMED, 2010) based on their investments in plant and machinery and their industry of operation.

a) Medium Enterprise : If the enterprise is engaged in the manufacturing industry, and has an investment in plant and machinery between Rs. 2.5 million and Rs. 50 million, it is classified as a small enterprise. In case the investment in plant and machinery exceeds Rs. 50 million and is below Rs. 100 million, it is classified as a medium enterprise.

b) If the enterprise is engaged in the service industry, and has an investment in plant and machinery between Rs. 1 million and Rs. 20 million, it is classified as a small enterprise and a medium enterprise if the investment in plant and machinery is between Rs. 20 million and Rs. 50 million (MSMED, 2010; DCMSME, 2014).

Figure 1

Definition of Small and Medium Enterprise

\begin{tabular}{|l|l|l|}
\hline & \multicolumn{2}{|l|}{ Investment in Plant and Machinery } \\
\hline & Small Enterprise & Medium Enterprise \\
\hline Manufacturing Sector & Rs. 2.5 million - Rs. 50 million & Rs. 50 million - Rs. 100 million \\
\hline Service Sector & Rs. 1 million - Rs. 20 million & Rs. 20 million - Rs. 50 million \\
\hline
\end{tabular}

Source: MSMED Act, 2006

Small and Medium Enterprises in India find it difficult to raise capital from banks and other financial institutions primarily due to the high element of risk involved with start-up and SME's in this nature of business. The secondary aspect is the access to centres of finance in India. Capital lenders are unevenly distributed across the country with majority of the financiers located in and around urban areas. Small businesses therefore are forced to acquire funds at a high cost of capital combined with other unfavourable compliance clauses. 
Acknowledging the fact that SME's play an integral role in sustaining the Indian economy, the need of the hour is to provide SME's access to capital markets at reasonable costs.

\section{SME EXCHANGE}

A stock exchange is a synonym for a market place where buyers and sellers assemble to trade in company stocks, bonds, commodities, currencies and other financially engineered products. A country can have multiple stock exchanges depending on the demand for such market places.

An SME exchange is a stock exchange created to enable Small and Medium Enterprises to gain access to financial capital from potential investors. While the primary role of the SME exchange is to provide funding there are additional benefits from enlisting on a public Exchange.

\section{Major SME Exchanges across the Globe and Their Models}

Out of the 192 countriesrecognized globally, 149 have an official stock exchange. And among those countries roughly 57 have an alternate market for small and medium companies to raise funds (Website SMEcapitalmarkets.net).

The alternate market functions mainly because the small and medium companies do not qualify for listing on the official stock markets due to stricter financial rules and regulation. The investor profile also differs in both the exchanges. While the main exchange attracts investors from all walks of life, the alternate exchange caters to a more educated investor who is aware of the risks involved in investing in start-up or growth companies.

These alternate markets operate with varying levels of success and efficiency.

Figure 2

SME Alternative Markets Global List

\begin{tabular}{|l|l|}
\hline Country & Alternative Market Name \\
\hline Australia & ASSOB, Bendigo Stock Exchange (BSX) \\
\hline Australia & Standard Market \\
\hline Argentina & Pyme Board \\
\hline Bosnia and Herzegovina & BLSE Free Market, SASE Free Market \\
\hline Brazil & Novo Mercado, BOVESPA MAIS \\
\hline Budapest & MMTS Unregulated Market System \\
\hline Canada & TSX Venture Exchange (TXS-V) \\
\hline China & Chinext, Small and Medium Enterprises Board \\
\hline Cyprus & $\begin{array}{l}\text { Alternative Market Investment Companies Market } \\
\text { Parallel Market }\end{array}$ \\
\hline Denmark & OMX First North \\
\hline Egypt & Nile Stock Exchange (NILEX) \\
\hline Finland & OMX First North \\
\hline France & Alternext \\
\hline Germany & Open Market, Entry Standard MiaccessBorseMunich \\
\hline Ghana & Ghana Stock Exchange - Second List \\
\hline
\end{tabular}




\begin{tabular}{|c|c|}
\hline Greece & ATHEX New Market, Alternative Market (ENA) \\
\hline Hong Kong & Growth Enterprise Market (GEM) \\
\hline Iceland & First North \\
\hline Ireland & Irish Enterprise Exchange (IEX) \\
\hline Italy & AIM Italia, Mercatio Alternative di Capitale (MAC) \\
\hline Japan & Mothers Market Hercules New Market JASDAQ NEO \\
\hline Kenya & Nairobi Stock Exchange AIMS \\
\hline Korea & KOSDAO \\
\hline Latvia & Riga Stock Exchange - First North \\
\hline Lithuania & Vilnius Stock Exchange (VSE) First North \\
\hline Lusaka & LSE Third Tier \\
\hline Luxemberg & Euro MTF \\
\hline Malawi & Malawi Stock Exchange - Alternative Capital Market \\
\hline Malaysia & ACE Market Second Board \\
\hline Malta & Alternative Companies List \\
\hline Mauritius & Development and Enterprise Market (DEM) \\
\hline Morocco & Casablanca Stock Exchange Growth Market \\
\hline Namibia & Namibia Stock Exchange Development Capital Board \\
\hline Netherlands, Belgium, Portugal & Alternext \\
\hline New Zealand & New Zealand Alternative Market (NZAX) \\
\hline Nordic Countries & First North Alternative Market \\
\hline Norway & OsloAxess \\
\hline Pakistan & KSE OTC \\
\hline Philippines & SME Board \\
\hline Poland & New Connect \\
\hline Russia & $\begin{array}{l}\text { The MICEX Stock Exchange Sector for Innovation and } \\
\text { Growth Companies }\end{array}$ \\
\hline Singapore & CATALIST \\
\hline SlovakRepublic & BSSE Regulated Free Market Listing Program \\
\hline Slovenia & LJSE Entry Market \\
\hline South Africa & $\begin{array}{l}\text { Alternative Exchange (AltX), Venture Capital Market, } \\
\text { Development Capital Market, Africa Board }\end{array}$ \\
\hline Sweden & Nordic Growth Market (NGM), OMX First North \\
\hline Switzerland & $\begin{array}{l}\text { SWX Local Caps Segment, SPI EXTRA, Bern } \\
\text { Exchange }\end{array}$ \\
\hline Taiwan & GRe Tai Securities Market (the GTSM) \\
\hline Tanzania & Enterprise Growth Market Segment \\
\hline Thailand & Market for Alternative Investment (MAI) \\
\hline Tunisia & Bourse de Tunis - Alternate Market \\
\hline Turkey & Second National Market, New Economy Market \\
\hline Uganda & $\begin{array}{l}\text { Uganda Securities Exchange - Alternative Investment } \\
\text { Market Segment (AIMS) }\end{array}$ \\
\hline United Kingdom & AIM PLUS Markets \\
\hline United States & AMEX - NYSE AmexEquities, Entrex, OTCBB \\
\hline Vienna & Second Regulated Market and Third Market (MTF) \\
\hline
\end{tabular}

Note: This list is not exhaustive. 
The Swiss SPI small and medium cap exchange leads the SME exchanges in market capitalization, followed by London stock exchange AIM and the Korean KOSDAQ. The top 15 SME exchanges based on their 2009 market capitalization are shown in the table below.

Figure 3:

Market Capitalisation (in USD Millions)

\begin{tabular}{|c|c|c|c|c|c|c|c|}
\hline Exchange & $\begin{array}{l}\text { Name of the } \\
\text { market }\end{array}$ & 2009 & 2008 & 2007 & $\begin{array}{l}\% \\
\text { change } 2009 / 2 \\
008\end{array}$ & $\begin{array}{l}\% \quad \text { change } \\
2009 / 2007\end{array}$ & $\begin{array}{l}\text { \%change } \\
2008 / 2007\end{array}$ \\
\hline $\begin{array}{ll}\text { SIX } & \text { Swiss } \\
\text { Exchange } & \end{array}$ & $\begin{array}{l}\text { SPIEXTRA } \\
\text { (small-and } \\
\text { mid-cap } \\
\text { sector) }\end{array}$ & 202099.0 & 161889.0 & 266251.2 & $24.84 \%$ & $-24.09 \%$ & $-39.20 \%$ \\
\hline London SE & AIM & 91445.2 & 54676.3 & 194189.9 & $67.25 \%$ & $-52.91 \%$ & $-71.84 \%$ \\
\hline Korea Exchange & Kosdao & 73938.3 & 34934.6 & 106694.9 & $111.65 \%$ & $-30.70 \%$ & $-67.26 \%$ \\
\hline TSX Group & TSX Venture & 34624.2 & 14098.6 & 58895.6 & $145.59 \%$ & $41.21 \%$ & $-76.06 \%$ \\
\hline BM\&FBOVESPA & $\begin{array}{l}\text { Organized } \\
\text { OTC market }\end{array}$ & 26922.6 & 17220.1 & 26314.3 & $56.34 \%$ & $2.31 \%$ & $-34.56 \%$ \\
\hline Shenzhen SE & ChiNext & 23584.0 & - & - & - & - & - \\
\hline Tokyo SE Group & Mothers & 15939.0 & 13560.3 & 24805.1 & $17.54 \%$ & $-35.74 \%$ & $-45.33 \%$ \\
\hline $\begin{array}{ll}\text { Hong } & \text { Kong } \\
\text { Exchanges } & \end{array}$ & $\begin{array}{l}\text { Growth } \\
\text { Enterprise } \\
\text { Market }\end{array}$ & 13545.9 & 5827.2 & 20658.3 & $132.46 \%$ & $-34.43 \%$ & $-71-79 \%$ \\
\hline Deutsche Borse & $\begin{array}{l}\text { Entry } \\
\text { Standard }\end{array}$ & 12076.5 & 10567.0 & - & $14.29 \%$ & - & - \\
\hline Osaka SE & $\begin{array}{l}\text { Nippon New } \\
\text { Market } \\
\text { Hercules }\end{array}$ & 7581.2 & 7784.3 & 15241.7 & $-2.61 \%$ & $50.26 \%$ & $-48.93 \%$ \\
\hline $\begin{array}{ll}\text { NYSE } & \text { Euronext } \\
\text { (Europe) } & \end{array}$ & Alternext & 5997.1 & 4523.9 & 8389.1 & $32.56 \%$ & $-28.51 \%$ & $-46.07 \%$ \\
\hline Singapore Exchange & SGX Catalist & 3793.0 & 2453.9 & 7029.8 & $54.57 \%$ & $-46.04 \%$ & $-65.09 \%$ \\
\hline $\begin{array}{l}\text { NASDAQ OMX } \\
\text { Nordic Exchange }\end{array}$ & Firth North & 2894.0 & 2166.1 & 2272.8 & $33.60 \%$ & $27.33 \%$ & $-4.70 \%$ \\
\hline Irish SE & $\begin{array}{l}\text { Irish } \\
\text { Enterprise } \\
\text { Exchange }\end{array}$ & 2314.3 & 1343.1 & 4506.6 & $72.31 \%$ & $-48.65 \%$ & $-70.20 \%$ \\
\hline Istanbul SE & $\begin{array}{l}\text { Second } \\
\text { National } \\
\text { Market }\end{array}$ & 1779.2 & 486.3 & 1434.8 & $269.80 \%$ & $24.00 \%$ & $-66.11 \%$ \\
\hline
\end{tabular}

Source: World Federation of Exchanges

Baring the Nordic First North exchange and the Brazilian OTC market, none of the top exchanges regained their 2007 market capitalization. However, almost all have registered double digit growth from their 2008 lows.

The Second National Market in Istanbul, TSX Venture in Canada, Growth Enterprise Market in Hong Kong and KOSDAQ in South Korea have more than doubled their SME market capitalization towards the end of 2009 compared to a year ago. During the same 
period the main stock markets in these four countries recorded only double digit growth figures, signalling the return of the investor confidence in the SME markets and the potential for growth post recession. The IPO markets saw a collapse across the board during the recession when compared to the peak in 2007. 107 SME's came out with an IPOin 2009 on TSX Venture compared to the 273 IPO's in 2007. On the AIM, 36 firms had an IPO offering in 2009 versus 284 firms in 2007 (Website SMEcapitalmarkets.net).

Figure 4

\begin{tabular}{|l|l|l|l|}
\hline \multicolumn{1}{|l}{ Market Capitalisation(USD Millions) } \\
\hline & 2007 & 2008 & 2009 \\
\hline SGX Catalist & 7000 & 2454 & 3793 \\
\hline Alternext & 8389 & 4524 & 5997 \\
\hline Hercules & 15242 & 7784 & 7581 \\
\hline Growth Enterprise Market & 20658 & 5827 & 13546 \\
\hline Mothers & 24805 & 13560 & 15939 \\
\hline Organized OTC Market & 26314 & 17220 & 26923 \\
\hline TSX Venture & 58896 & 14099 & 34624 \\
\hline Kosdaq & 106695 & 34935 & 73938 \\
\hline AIM & 194190 & 54676 & 91445 \\
\hline SPI EXTRA & 266251 & 161889 & 202099 \\
\hline
\end{tabular}

Source:World Federation of Exchanges

\section{Listed Companies}

TSXVenture has almost double the number of companies listed on it as its nearest competitor AIM. While TSX had steadily maintained the number of companies listed on the exchange from 2007, AIM went through a delisting crisis taking a 24 percent hit during the same period. Roughly 400 companies have departed from AIM since 2007 citing the high costs associated with listing on the AIM (ranges between $£ 60,000$ to $£ 250,000$ per annum), lack of liquidity, lower demand and unfavourable valuation as major reasons for delisting (Website SMEcapitalmarkets.net). A few firms have cited takeover activity as their major motive for leaving.

AIM, however, retains the spot as the SME exchange with the largest number of listings in Europe, followed by SPI and Alternext. In the Asian markets, the KOSDAQ had been successful in retaining and attracting high growth and newly emerging technology companies during the recession time frame. 
Figure 5

Number of Companies Listed

\begin{tabular}{|c|c|c|c|}
\hline & 2007 & 2008 & 2009 \\
\hline Organized OTC Market & 89 & 89 & 82 \\
\hline Alternext & 119 & 128 & 125 \\
\hline SGX Catalist & 157 & 133 & 134 \\
\hline Nippon New Market "Hercules" & 173 & 170 & 150 \\
\hline Growth Enterprise Market & 193 & 174 & 174 \\
\hline Mothers & 197 & 198 & 185 \\
\hline SPI EXTRA(small- and mid-cap sector) & 205 & 209 & 202 \\
\hline Kosdaq & 1022 & 1037 & 1026 \\
\hline AIM & 1694 & 1550 & 1293 \\
\hline TSX Venture & 2338 & 2443 & 2375 \\
\hline
\end{tabular}

Source:World Federation of Exchanges

\section{New Capital Raised}

The AIM market in London has raised in excess of $\$ 100$ Billion for its listed companies up until the end of 2009. The availability of finance from the UK market has led even foreign companies to list on the AIM market place. Currently about 20 percent of the firms listed on the AIM are foreign companies. TSX Venture market on the other hand consists of mainly domestic companies (Website SMEcapitalmarkets.net).

The KOSDAQ stands out as the best exchange to raise capital in the Asian markets. Firms listed on the KOSDAQ continued to raise capital during the recessionary periods. The other major markets in Asia for raising capital are GEM (Hong Kong), Mothers (Japan) and CATALIST (Singapore).

Figure 6: New Capital Raised

\begin{tabular}{|l|l|l|l|}
\hline & \multicolumn{3}{l|}{ New Capital raised (USD Million) } \\
\hline & 2007 & 2008 & 2009 \\
\hline SGX Catalyst & 240 & 131 & 74 \\
\hline Alternext & 942 & 625 & 247 \\
\hline Mothers & 748 & 422 & 411 \\
\hline Growth Enterprise Market & 2534 & 1164 & 566 \\
\hline Kosdaq & 1426 & 2083 & 2476 \\
\hline TSX Venture & 10936 & 5132 & 4185 \\
\hline AIM & 32458 & 7852 & 8621 \\
\hline
\end{tabular}




\section{FUNDING SITUATION IN INDIA}

\subsection{Capital Access Index}

The capital access index is a measure of the ability of businesses and entrepreneurs to access domestic and foreign capital in the country. India is currently ranked $47^{\text {th }}$ amongst 122 nations. China is marginally ahead at 45 while Brazil and Russia are at 51 and 58 respectively. The index is derived after considering seven parameters of the economy (Angkinand et al, 2009).

Figure 7

Capital Access Index Parameter

\begin{tabular}{|l|l|}
\hline & Capital Access Index Parameters \\
\hline Contributing Parameters & India's Rank \\
\hline Equity Market Development & 22 \\
\hline Alternate Sources of Capital & 28 \\
\hline Bond Market Development & 33 \\
\hline Institutional Environment & 49 \\
\hline Financial and Banking Institutions & 59 \\
\hline Marcoeconomic Environment & 60 \\
\hline International Funding & 75 \\
\hline
\end{tabular}

Source: Miken Institute

India is ahead on equity and bond market development but falls behind in providing access to international funding and creating a macroeconomic environment for businesses to develop. India's drop on the capital access index has been mainly due to the low scores in financial and banking institutions. India seems to be fairly placed in alternate sources of capital which refers to funding from venture capital, private placements, credit cards and other forms of alternative financing.

While the Capital Access Index takes into consideration the Indian economy as a whole, let us consider the case of an SME.

Figure 8

Capital Access Index

\begin{tabular}{|l|l|l|}
\hline Rank 2008 & Rank 2007 & Country \\
\hline 1 & 3 & Canada \\
\hline 2 & 1 & Hong Kong \\
\hline 3 & 7 & Switzerland \\
\hline 4 & 2 & United Kingdom \\
\hline 5 & 4 & Singapore \\
\hline 6 & 11 & United States \\
\hline 7 & 15 & Netherlands \\
\hline 8 & 9 & Norway \\
\hline 9 & 8 & Australia \\
\hline 10 & 9 & Finland \\
\hline 11 & 5 & Sweden \\
\hline
\end{tabular}


Can SME exchange really play a vital role in accelerating Start-Up Growth?

\begin{tabular}{|c|c|c|}
\hline 12 & 19 & South Korea \\
\hline 13 & 14 & Denmark \\
\hline 14 & 13 & Malaysia \\
\hline 15 & 19 & Estonia \\
\hline 16 & 15 & Japan \\
\hline 17 & 22 & France \\
\hline 18 & 6 & Ireland \\
\hline 19 & 18 & New Zealand \\
\hline 20 & 29 & United Arab Emirates \\
\hline 21 & 12 & Israel \\
\hline 22 & 21 & Belgum \\
\hline 23 & 17 & Germany \\
\hline 24 & 25 & Taiwan,China \\
\hline 25 & 23 & Austria \\
\hline 26 & 24 & Portugal \\
\hline 27 & 43 & Spain \\
\hline 28 & 30 & South Africa \\
\hline 29 & 27 & Chile \\
\hline 30 & 33 & Italy \\
\hline 31 & 32 & Kuwait \\
\hline 32 & 26 & Thailand \\
\hline 33 & 42 & Oman \\
\hline 34 & 28 & Lithuania \\
\hline 35 & 37 & Czech Republic \\
\hline 36 & 31 & Hungary \\
\hline 37 & 36 & Saudi Arabia \\
\hline 38 & 40 & Panama \\
\hline 39 & 48 & Lebanon \\
\hline 40 & 44 & Slovakia \\
\hline 41 & 34 & Greece \\
\hline 42 & 47 & Jordan \\
\hline 43 & 39 & Poland \\
\hline 44 & 35 & Mexico \\
\hline 45 & 45 & China \\
\hline 46 & 46 & Slovenia \\
\hline 47 & 41 & India \\
\hline 48 & 53 & Bulgaria \\
\hline 49 & 54 & Croatia \\
\hline 50 & 51 & Turkey \\
\hline
\end{tabular}

\subsection{SME Funding Sources}

The issue an SME faces is more about the high cost of capital rather than easy access to capital. Listing on the equity market would incur huge financial and compliance costs that 
would make it economically unviable for an SME. Approaching the bond market without sufficient collateral would lead to high interest rate loans from the lenders.

Depending on the financial sophistication of the SME, other debt funding options are available from domestic and overseas foreign currency borrowings and foreign currency convertible bonds. While foreign currency borrowing may yield rates that are lower than the domestic market rates, knowledge of the financial instruments and the risks involved is necessary for an SME. For an average SME, with limited financial knowledge, this would further complicate matters.

Risk capital as a source of funding has been growing steadily over the past few years. Private Equity (PE) players investing in the India economy crossed 300 as of 2009. The number of Venture Capitalists (VC) and Angels funding business ideas grew to 60 in 2009. The PE's and VC's operate in a few niche industries and deal mainly with new age business ideas that have the ability to grow exponentially in a few years (Acharya, 2006).

The National Science and Technology Entrepreneurship Development Board (NSTEDB) and Development Commissioner Micro, Small and Medium Enterprises (DCMSME) have set up close to 70 Technology Business Incubators (TBI) in India to nurture start-ups. However, grants and other capital funding are provided only to firms setting up offices on TBI's premises (NSTEDB, 2014).

\subsection{Limitations of the Entire Investing Space}

I. Cost of accessing Equity Capital is prohibitively high for the SME.

II. Cost of accessing Debt Capital is not economically viable due to security and collateral requirements from the lenders.

III. Lack of credibility or trust on the SME players while borrowing capital.

IV. Amount of funding available is inadequate to meet the needs of the SME

\section{PAST EFFORTS OF SME EXCHANGE}

\subsection{Over The Counter Exchange of India (OTCEI) (Srinivasan, 2000; Ghosh, 1996; OTCEI, 2012)}

The OTCEI platform was launched in 1992 to accomplish the need of an SME exchange in India. Modelled along the lines of the National Association of Securities Dealers Automated Quotation System (NASDAQ), many of the features listed were new to the Indian market and were considered ahead of its times. The platform however failed to gather momentum and was eventually out of business. The major drawbacks of the OTCEI were:

I. Liquidity concerns of stocks

II. Lack of marketing by the OTC about the uniqueness of the exchange and its scripts

III. Technology discouraged speculation, which was necessary for driving volumes and liquidity

IV. Stringent regulations for listing 
V. The low volumes and lack of activity affected the stock performance causing the index and shareholders to lose value.

VI. Changed strategy from being a dedicated SME exchange to one serving all companies listed on the Bombay Stock Exchange (BSE) and National Stock Exchange (NSE).

\subsection{Indonext}

A project initiated by the Bombay Stock Exchange in 2005 to list small and medium companies on a separate platform. The exchange was plagued by:

I. Lack of liquidity on the regional stock exchange and coordination between them.

II. Insufficient information available about the new SME's

III. Excessive regulation from the government.

IV. Firms listed on the B1 and B2 groups on the BSE exchange were shifted to the new exchange confusing investors about the actual intent of Indonext

V. Credibility of the listed firms

VI. Lack of marketing and awareness among consumers and institutions

VII. Stringent guidelines for listing on the exchange

\subsection{How an SME Exchange would be Beneficial in this Scenario}

The establishment of an SME Exchange is the first step towards creating a formal platform for interaction between SME business entrepreneurs and investors. In addition it would:

1. Lower the cost of capital for small and medium businesses.

2. Provide an exit opportunity for VC's and PE's

3. Ease of access to capital."Raising money through the public markets is easier. In the startup stages, I am not sure if it would help us but once we have a beta product and have invested a lot into it we will go to the exchange." , KausikMandal, V.P of operations and business development in RFIC solutions

4. Aid to raise high volume of capital. "Because of the number of investors, volume of availability of capital is higher in an exchange", KausikMandal, V.P of operations and business development in RFIC solutions.

5. Improves the image of the SME by adding 'Trust' and 'Credibility'. "Listing on the SME exchange would definitely improve the company's image. There's no doubt about it.", YadavChandna, Director of Sai Products and Graphics, an SME based out of NOIDA said "Start-ups face a lot of issues. The main issue is that clients don't trust our credentials. Listing on an SME exchange adds a lot of credibility that is useful not only for my clients but also for my vendors, employees and banks', Feby Joseph, Co-Founder at Roovno Web Ventures, a start-up based out of Bangalore.

6. Improved corporate governance and accountability in the SME. "It will eventually lead to better governance. At any point of time if external funding comes in, then there is always going to be a requirement for corporate governance, but at what cost? If the overhead 
associated with it is high, I might not consider listing on the SME exchange"(UmeshSisodia, CEO of Circuitsutra, an SME based out of NOIDA)

7. Better management. "Raising money from the public is easier and in the long run it is a better way of running a company", "While there are a few exceptions, Venture Capital firms in general have their own agenda and tend to run the company when they are on board", KausikMandal, V.P of operations and business development in RFIC solutions

8. Enhanced visibility for Small and Medium Enterprise. "It definitely increases the visibility of the company in the market. It creates 360 degree value across the chain", Yogesh Bansal, CEO of Apnacircle.com, a social networking site based out of NOIDA

9. Healthier valuation of the SME. "The SME would be able to get the right kind of valuation in the market when compared to a VC or PE", UmeshSisodia, CEO of Circuitsutra, an SME based out of NOIDA

10. Dress rehearsal for the main stock exchange

\subsection{Shortcomings of an SME Exchange}

1. Lack of expertise mentoring and networking as in the case of a PE or VC investor.

Not all SME's agree that having an exchange is the best solution. Yogesh Bansal, the $\mathrm{CEO}$ of Apnacircle, is of the opinion that having a PE or a VC investor on the board of the company is very beneficial. "I don't think that the cost is too high in the long term. The expectation of a PE is higher than the capital markets, so the initial cost of capital might be higher, but there is a lot of other benefits included like mentoring, handholding, networking, that is more beneficial to my firm. It really depends on business to business."

2. An average retail investor might not be able to effectively judge the risk involved in investing in an SME.

3. Difficulty in gauging the value of a Dotcom company."For a manufacturing company, it is relatively easier to raise funds. But in the case of a Dotcom firm, there are no tangible assets. How will the market value my firm?", Yogesh Bansal, the CEO of Apnacircle.

4. Liquidity will decrease if the investor demand and traded volume is low and vice versa.

5. Unfamiliarity with the exchange model "The SME exchange is a new model and it is difficult to compare a non existing model with a PE/VC framework." Says Umesh, CEO of Circuitsutra technologies

6. During periods of economic turmoil, the SME's would not be able to raise fresh capital from the markets.

7. A high cost of compliance will prevent SME's from approaching the exchange.

8. Risk of the business failing is higher than the main exchange.

9. Start ups or loss making SME's may not be allowed to list on the exchange. 
10. Building trust in the SME exchange and making it successful will take considerate amount of effort and time from the market participants and the regulator."How can an investor trust an SME company? Are there stringent laws protecting the investor? The process of setting up an SME exchange will take time. It will not grow suddenly", YadavChandna, Director of Sai Products and Graphics, an SME based out of NOIDA.

\subsection{What Should be Looked into in the Future SME Exchange?}

Consideration for future the SME exchange

a) Before creating the exchanges, an ecosystem consisting of market makers, advisors, brokers, investment banks, financial institutions must be created to ensure that there is a lot of handholding for the SME's when they list on the exchange.

b) A vibrant and prolonged marketing campaign that educates the SME investor about the unique offering of the SME exchange must be launched.

c) The SME firms listing on the exchange must be monitored by independent third party agencies to check for credibility.

d) Exchange rules and regulations must be reduced to a minimum level so that the cost of listing on the exchange is not prohibitive for the SME.

e) The core focus of the SME exchange must be to help small and medium enterprises obtain funds.

\section{DIRECTIONS FOR THE FUTURE}

The current financial environment in India is inadequate for SME's and start-ups to transform into corporate that can take on the large scale manufactures in India and abroad. The biggest concern for entrepreneurs in the financial arena is not the lack of capital but the cost of capital. Opening up new avenues to finance growth in the SME's would lead to a revolution in India in the SME space. The most feasible option would be to allow the entrepreneurs from small and medium companies approach investors directly in the open market through an SME exchange along the lines of the BSE or NSE in India. However the task is easier said than done. While there will always be genuine SME's pursuing the markets for capital, utmost care should be taken in the form of regulations that protect the investor's capital from fraud and other malicious players in the SME market.

Setting up am exchange would be part of the solution, making sure that the exchange is sustainable in the long run is the real solution. We have failed twice in the past as seen in the case of OTCEI and Indonext. There are lessons that can be learnt from both these scenarios. The next effort on the Indian soil cannot sustain itself with the help of the regulatory bodies alone; the whole ecosystem surrounding it has to be strengthened. We need not reinvent the wheel in our quest for a workable solution. There exists a great SME exchange model around the world that we can benchmark upon. The AIM in UK, TSX-V in Canada, SPI small and Medium in Switzerland and KOSDAQ in South Korea are all examples of successful exchanges with a great supporting ecosystem. While it would be fatal to blindly borrow the best practices in these exchanges, a workable solution we need to pursue would necessarily have to be in accordance with the Indian environment. 
The Catalyst for SME growth in our country has been identified and if we succeed in making the SME exchange as successful as the NSE stock exchange, we are indeed in for a new chapter in India's Small and Medium Enterprises growth story.

\section{REFERENCES}

Acharya, P.K. (July-Sept 2006), "Alternate low cost fund raising avenues for the SME sector", College of Agricultural Banking, CAB Calling

Angkinand, A., Barth, J.R., Wenling Lu T.L., and Yago, G., (April 2009), Capital Access Index 2008" Best Markets for Business Access to Capital, Milken Institute.

Asian Development Bank, (2012), Micro, Small, and Medium Enterprise Development Project

Project

Loan, http://pid.adb.org/pid/LoanView.htm?projNo=43158\&seqNo=01\&typeCd=3, accessed on May 12, 2012

Development Commissioner Micro, Small and Medium Enterprises website http://www.dcmsme.gov.in , accessed on January 12, 2014

Ghosh, S. (November 27, 1996), "OTCEI, an Inglorious End", Outlookindia.com http://www.outlookindia.com/article.aspx?202597, accessed on November 27, 1996

Information Age, (August 11, 2009), "Looking for life after delisting", http://www.information-age.com/cover-stories/1065187/looking-for-life-after-delisting.thtml, accessed on August 11, 2009

Maniamala, M. J., Gopal, M.V., and Sridhar, P. (2002), "India Report", Global Entrepreneurship Monitor

Ministry of Micro, Small \& Medium Enterprises, (February 2010), "Report of the task force on MSME"

National Science and Technology Entrepreneurship Development Board website http://www.nstedb.com , accessed on March 21, 2014

Over the counter exchange of India website. http://www.otcei.net/about/, accessed on March 21,2012

Srinivasan, R. (August 13, 2000), "Whither OTCEI?", website of Hinduonnet.com. http://www.hinduonnet.com/businessline/iw/2000/08/13/stories/0813h051.htm, accessed on August 13, 2000

Endnotes:

Interviews

$$
\begin{aligned}
\text { i. } & \text { Feby Joseph - CEO of Roovo.com } \\
\text { ii. } & \text { KausikMandal - V.P Operations of RFIC solutions.com } \\
\text { iii. } & \text { UmeshSisodia - CEO of Circuitsutra.com } \\
\text { iv. } & \text { YadavChandna - Director of Sai Products \& Graphics } \\
\text { v. } & \text { Yogesh Bansal - CEO of Apnacircle.com }
\end{aligned}
$$

